Fikrah: Jurnal Ilmu Aqidah dan Studi Keagamaan

issn 2354-6147 eissn 2476-9649

Tersedia online di: journal.stainkudus.ac.id/index.php/Fikrah

DOI: https://doi.org/10.21043/fikrah.v4i1.1664

Artikel diserahkan : 31 Agustus 2016; Diterima: 3 Oktober 2016

\title{
Peran Kecerdasan Emosi Dalam Meningkatkan Toleransi Beragama
}

\author{
M. Nur Ghufron \\ STAIN Kudus, Indonesia \\ emnurghufron78@gmail.com
}

\begin{abstract}
Abstrak
Tujuan dari penelitian ini adalah untuk mengetahui hubungan antara kecerdasan emosi dengan toleransi beragama. Subyek penelitian ini adalah mahasiswa Pendidikan Agama Islam, Jurusan Tarbiyah, Sekolah Tinggi Agama Islam Kudus. Sampel $(\mathrm{N}=94)$ dikumpulkan melalui convenience sampling, dengan mengisi angket dalam bentuk skala. Berdasarkan hasil analisis diperoleh $r=0,458 ; p=0,000$. Dengan demikian, hipotesis yang menyatakan bahwa ada hubungan positif yang signifikan antara kecerdasan emosi dengan toleransi beragama mahasiswa terbukti. Selain itu diperoleh koefesien determinasi sebesar 0.209 , yang berarti kecerdasan emosi mempunyai sumbangan efektif 20 persen terhadap toleransi beragama mahasiswa. Hasil penelitian menunjukkan bahwa ada hubungan yang signifikan positif antara kecerdasan emosi dengan toleransi agama.
\end{abstract}

Kata kunci: Kecerdasan emosi, toleransi beragama 


\begin{abstract}
The aim of the present study was to determine the relationship between emotional intelligence and religious tolerance. The subjects of this study were students of Department of Islamic Education in Islamic Studies Collage in Kudus. The samples $(\mathrm{N}=94)$ were collected using convenience sampling method where questionnaires were completed in the form of scale. The results of the study showed $r=0,458 ; p=0,000$. It was found that there was relationship between emotional intelligence and religious tolerance. Additionally, the coeffecient determinant showed 0209, which means the effective contribution of emotional intelligence, has 20 percent of the student religious tolerance. The results of the study showed that there was a positive significant relationship between Emotional Intelligence and religious tolerance.
\end{abstract}

Keywords: Emotional intelligence, religious tolerance

\title{
Pendahuluan
}

Bangsa Indonesia bukanlah sebuah negara teokrasi, melainkan secara konstitusional negara mewajibkan warganya untuk memeluk satu dari agamaagama yang diakui eksistensinya sebagaimana tercantum di dalam pasal 29 ayat (1) dan (2) UUD 1945. Negara memberi kebebasan kepada penduduk untuk memilih salah satu agama yang telah ada di Indonesia yaitu agama Islam, Kristen Protestan, Kristen Katolik, Hindu, Budha dan Konghuchu. Kenyataan ini dengan sendirinya memaksa negara untuk terlibat dalam menata kehidupan beragama.

Ketentuan dalam pasal 29 UUD 1945 sangat penting artinya bagi agama-agama dan para pemeluknya karena telah memberi jaminan dan sarana keterlibatan umat di dalam mengisi dan memperkaya kehidupan berbangsa. Tiap pemeluk agama mendapatkan kesempatan untuk menjalankan agama dan menciptakan kehidupan beragama secara toleran dan sesuai dengan ajaran agama masing-masing.

Fenomena yang berkembang saat ini adalah bahwa toleransi beragama menjadi sesuatu yang perlu ditangani secara serius. Beberapa fakta terjadi yang menjadikan toleransi menjadi sesuatu yang mahal seperti yang dilaporkan Majalah Tempo pada tanggal 23 Februari 2016 kejadian di Bogor yang menyegel Gereja Kristen Indonesia Yasmin yang hingga sekarang belum usai. Sementara di Bandung ada pelarangan operasional terhadap tujuh gereja di pada pertengahan Juni 2015. Ahmadiyah termasuk salah satu yang mendapat perlakuan tak enak di Jawa Barat. Kelompok tersebut kerap mengalami diskriminasi di Jawa Barat, mulai larangan beribadah hingga berkumpul.

Di Jawa Tengah, sebagaimana yang telah diberitakan oleh Suara Merdeka, tanggal 4 Juni 2014 yang mengutip dari pendokumentasian Lembaga Studi Sosial dan Agama (eLSA), bahwa sampai enam bulan pertama pada 2014, terjadi enam 
kasus kekerasan mengatasnamakan agama. Kasus-kasus tersebut seperti kasus pendirian Gereja Injili di Tanah Jawa (GITJ) Dermolo, Jepara misalnya. Peristiwa itu sudah berlangsung sejak 2002, dan tak kunjung ada penyelesaian hingga sekarang. Kasus serupa juga terjadi di kalangan penghayat kepercayaan. Enam kasus tersebut diantaranya perusakan tempat ibadah umat Hindu di Dukuh Giriloka, Desa Girimargo, Kecamatan Miri, Kabupaten Sragen oleh orang tak dikenal. Perusakan diperkirakan terjadi 16 Januari dan kemudian baru diketahui pada 19 Januari. Selanjutnya, bentrok warga dengan FPI di Wonosobo, pembubaran pengajian Majelis Tafsir Al-Qur'an (MTA) di Desa Megoten, Kecamatan Kebonagung, Kabupaten Demak, 13 Februari. Kemudian penolakan kedatangan Habib Rizieq di Kecamatan Bonang, Kabupaten Demak pada 8 Mei, dan Camat Grobogan yang menyoal pengajian Jantiko Mantab Dzikrul Ghofilin pada 11 Maret, serta penangkapan terduga teroris di Klaten pada 14-15 Mei oleh Densus 88 Anti Teror. Selain itu di luar Jawa ada penyerangan dan pembakaran tempat ibadah yang terjadi di Papua waktu hari raya Idul Fitri tahun 2015 dan lain- lain.

Toleransi antar umat beragama berarti menghormati dan peduli terhadap pemeluk agama lain, tidak memaksa mereka mengikuti agamanya dan tidak mencampuri urusan agama masing-masing. Toleransi beragama adalah "mengakui dan mendukung bahwa individu memiliki hak dan kebebasan untuk keyakinan mereka sendiri dan praktik yang sah terkait, tanpa harus memvalidasi keyakinan atau praktik" (Hein dalam Risnawita dan Ghufron, 2015, hal. 2).

Menurut Puslitbang Kehidupan Keagamaan Badan Litbang dan Diklat Kementerian Agama RI (2010, hal. v) Toleransi merupakan elemen dasar yang dibutuhkan untuk menumbuhkembangkan sikap saling memahami dan menghargai perbedaan yang ada, serta menjadi entry point bagi terwujudnya suasana dialog dan kerukunan antar umat beragama dalam masyarakat. Agar tidak terjadi konflik antar umat beragama, toleransi harus menjadi kesadaran kolektif seluruh kelompok masyarakat, dari tingkat anak-anak, remaja, dewasa, hingga orang tua, baik pelajar, pegawai, birokrat maupun mahasiswa. Lebih dari itu, prinsip-prinsip toleransi harus betul-betul bekerja mengatur perikehidupan masyarakat secara efektif. Salah satu subelemen penting masyarakat dalam rangka menjaga tetap bekerjanya prinsipprinsip toleransi adalah para mahasiswa.

Sikap toleransi beragama terkait erat dengan kegagalan penguasaan diri, sehingga perlunya kecerdasan emosi. Kesadaran akan pentingnya kecerdasan emosi dimasa ini sangat mendesak untuk dikedepankan. Alasan yang dapat dikemukakan diantaranya adalah :

Pertama kecerdasan emosi adalah salah satu kunci keberhasilan hidup, orang yang cerdas secara emosi sadar akan keadaan diri dan orang lain, memiliki motivasi dan optimisme. Goleman (1995, hal. 34) menyatakan bahwa dari sekian faktor yang menentukan kesuksesan seseorang, kognitif hanya menyumbang kira-kira 20 persen, maka yang 80 persen diisi oleh kekuatan-kekuatan lain termasuk yang disebutnya sebagai kecerdasan emosi. 
Senada dengan Goleman, Tice, Bratelavisky dan Baumemister (2001, hal. 351356) juga menekankan bahwa kemampuan untuk mengontrol dan mengatur impuls, emosi, hasrat, performance dan perilaku lainnya adalah merupakan keutamaan diri dan merupakan salah satu aspek yang penting, untuk mencapai kesuksesan dan kebahagiaan hidup. Kegagalan dalam mengontrol diri termasuk emosi, akan berdampak pada problem personal maupun sosial dalam spektrum yang luas, mulai dari adanya indikasi kekerasan, kenakalan, kriminalitas, kekerasan dalam rumah tangga, kegagalan sekolah, hutang dan kepailitan sampai kepada terjangkitnya penyakit seksual.

Kedua menurut Calhoum \& Acocella dalam Prayitno (2007, hal. 2), setiap individu tidak hidup sendiri tetapi dengan orang lain dalam kelompok masyarakat, sehingga pengendalian diri itu penting baik untuk mencapai tujuan pribadi maupun untuk dapat bergaul dengan orang lain. Orang yang cerdas secara emosi mampu mengelola emosi dalam diri sehingga tidak saja dapat memuaskan gejolak dan kebutuhan yang ada pada dirinya tetapi juga ekspresi emosi itu dapat diterima secara sosial.

Ketiga faktor emosi yang ada pada manusia berpengaruh dalam setiap aspek kehidupannya. Adam dkk dalam Lagattuta \& Wellman (2002, hal. 115) menyatakan bahwa emosi berpengaruh pada cara seseorang mempersepsi, merespon orang atau peristiwa, emosi dapat juga memberi inspirasi atau melemahkan semangat, memberi dukungan atau justru mengacaukan hubungan interpersonal. Orang yang cerdas secara emosi senantiasa mampu melihat situasi yang krisis sebelum merespon secara emosional yang pada gilirannya mampu memutuskan dengan tepat apa yang harus dilakukan.

Beberapa penelitian menunjukkan bahwa kecerdasan emosi turut memberikan konstribusi terhadap proses hidup yang dijalani seseorang dengan lingkungannya. Djuwarijah dalam Prayitno (2007, hal. 6) meneliti tentang Hubungan Kecerdasan Emosi dan Pengasuhan Islami dengan agrasifitas remaja, menyimpulkan bahwa semakin tinggi tingkat kecerdasan emosi seseorang, maka semakin rendah pula tingkat agresif remaja.

Seharusnya kemampuan individu dalam menggunakan aspek kecerdasan emosi yang tercermin dalam kemampuannya untuk mengenali, memahami, menghargai, mengekpresikan, menggunakan dan mengendalikan emosi diri dan emosi orang lain sudah ada dalam setiap individu. Namun demikian kecerdasan emosi dewasa ini berada pada tingkat yang memprihatinkan, tak saja di Indonesia tetapi merupakan kecendrungan diseluruh dunia. Sebuah survey besar-besaran terhadap orangtua dan guru memperlihatkan adanya kecenderungan yang sama diseluruh dunia, yaitu generasi sekarang lebih banyak mengalami kesulitan emosional dari pada generasi sebelumnya, lebih kesepian dan pemurung, lebih kasar dan kurang menghargai sopan santun, lebih gugup dan mudah cemas, lebih implusif dan agresif. Kemampuan mengendalikan perilaku dimiliki individu, kesadaran akan keberadaan diri, sikap rela menerima kenyataan adalah aspek-aspek kecerdasan emosi (Goleman: 1995, hal. xii). 
Menurut Brackett, Mayer and Warne dalam Priyadarshini Das dan Tripathy (2015), kecerdasan emosional memerankan peran penting dalam hubungan interpersonal remaja. Remaja yang mempunyai kecerdasan emosional yang rendah mempunyai kecenderungan perilaku penyalah gunaan obat bius, kriminalitas dan kekerasan, depresi, kehamilan tak dikehendaki.

Berdasarkan penjelasan di atas dapat ditarik kesimpulan mengenai pentingnya kecerdasan emosional dalam kehidupan sehari-hari terutama berkaitan tentang hubungan interpersonal individu yang satu dengan lainnya terutama dalam meningkatkan toleransi agama. Oleh karena itu, tujuan penelitian ini adalah untuk membuktikan peran kecerdasan emosional terhadap toleransi beragama.

\section{Toleransi agama}

Menurut Manaf (1994, hal. 1), kata agama dalam bahasa Indonesia sama dengan "diin"(dari bahasa Arab) dalam bahasa Eropa disebut "religi", religion (bahasa Inggris), la religion (bahasa Perancis), the religie (bahasa Belanda), die religion, (bahasa Jerman). Kata "diin" dalam bahasa Semit berarti undang-undang (hukum), sedang kata diin dalam bahasa Arab berarti menguasai, menundukkan, patuh, hutang, balasan, kebiasaan.

Nasution (1985, hal. 10) telah mengumpulkan delapan macam definisi agama yaitu: pertama, pengakuan terhadap adanya hubungan manusia dengan kekuatan gaib yang harus dipatuhi. Kedua, pengakuan terhadap adanya kekuatan gaib yang menguasai manusia. Ketiga, mengikatkan diri pada suatu bentuk hidup yang mengandung pengakuan pada suatu sumber yang berada di luar diri manusia dan yang mempengaruhi perbuatan-perbuatan manusia. Keempat, kepercayaan pada suatu kekuatan gaib yang menimbulkan cara hidup tertentu. Kelima, suatu sistem tingkah laku yang berasal dari suatu kekuatan gaib. Keenam, pengakuan terhadap adanya kewajiban-kewajiban yang diyakini bersumber pada suatu kekuatan gaib. Ketujuh, pemujaan terhadap kekuatan gaib yang timbul dari perasaan lemah dan perasaan takut terhadap kekuatan misterius yang terdapat dalam alam sekitar manusia. Terakhir, ajaran-ajaran yang diwahyukan Tuhan kepada manusia melalui seorang Rasul.

Anshori dalam Ghufron dan Risnawita (2010, hal. 167) membedakan antara istilah religi atau agama dengan religiusitas. Jika agama menunjuk pada aspek-aspek formal yang berkaitan dengan aturan dan kewajiban, maka religiusitas menunjuk pada aspek religi yang telah dihayati oleh seseorang dalam hati. Religiusitas sebagai keberagamaan karena adanya internalisasi agama tersebut ke dalam diri seseorang.

Agama adalah hubungan antara makhluk dengan Khalik (Tuhan) yang berwujud ibadah yang dilakukan dalam sikap kesehariaannya. Arti agama secara detail bahwa agama sebagai suatu sistem credo (tata keyakinan) atas adanya Yang Maha Mutlak dan suatu sistem norma (tata kaidah) yang mengatur hubungan manusia dengan sesama manusia dan dengan alam sekitarnya, sesuai dengan tata keimanan dan tata peribadatan tersebut (Ghufron dan Risnawita, 2010, hal. 167). 
Pargament (dalam Ghufron dan Risnawita, 2015, hal. 58) mendefinisikan agama dalam arti luas dan multidimensi termasuk ekspresi keagamaan institusional, seperti dogma dan ritual, dan ekspresi keagamaan, seperti perasaan spiritualitas, keyakinan tentang yang suci, dan agama adalah praktek.

Dari berbagai pendapat di atas dapat ditarik kesimpulan bahwa agama menunjuk pada tingkat keterikatan individu terhadap agamanya. Hal ini menunjukkan bahwa individu telah menghayati dan menginternalisasikan ajaran agamanya sehingga berpengaruh dalam segala tindakan dan pandangan hidupnya.

Sementara berkatan tentang toleransi, Secara etimologi berasal dari kata tolerance (dalam bahasa Inggris) yang berarti sikap membiarkan, mengakui dan menghormati keyakinan orang lain tanpa memerlukan persetujuan. Di dalam bahasa Arab dikenal dengan tasamuh, yang berarti saling mengizinkan, saling memudahkan (Al-Munawar, 1987, hal. 13). Adapun menurut Webster's New American Dictionary arti tolerance adalah liberty toward the opinions of others, patience with others yang kalau diterjemahkan ke dalam Bahasa Indonesia artinya adalah memberi kebebasan (membiarkan) pendapat orang lain, dan berlaku sabar menghadapi orang lain (Puslitbang Kehidupan Keagamaan Badan Litbang dan Diklat Kementerian Agama RI, 2010, hal. 51). Jadi toleransi adalah sikap lapang dada terhadap prinsip orang lain, tidak berarti seseorang harus mengorbankan kepercayaan atau prinsip yang dianutnya melainkan harus tercermin sikap yang kuat atau istiqamah untuk memegangi keyakinan atau pendapatnya sendiri.

Khisbiyah (2007, hal. 4) berpendapat bahwa toleransi adalah kemampuan untuk menahankan hal-hal yang tidak kita setujui atau tidak kita sukai, dalam rangka membangun hubungan sosial yang lebih baik. Toleransi mensyaratkan adanya penerimaan dan penghargaan terhadap pandangan, keyakinan, nilai, serta praktik orang/kelompok lain yang berbeda dengan kita. Intoleransi adalah ketidakmampuan atau ketidakmauan untuk bertoleran, muncul karena kita tidak bisa atau tidak mau menerima dan menghargai perbedaan. Intoleransi bisa terjadi pada tataran hubungan interpersonal, seperti hubungan antara kakak dan adik, orangtua dan anak, suami dan isteri, antarteman, atau antarkelompok, misalnya suku, agama, bangsa, dan ideologi.

Menurut Puslitbang Kehidupan Keagamaan Badan Litbang dan Diklat Kementerian Agama RI, (2010, hal. 57) yang mengutip dari Ensiklopedi Nasional Indonesia menjelaskan bahwa, toleransi beragama adalah sikap bersedia menerima keanekaragaman dan kebebasan beragama yang dianut dan kepercayaan yang diyakini oleh pihak atau golongan lain. Hal ini dapat terjadi karena keberadaan dan eksistensi suatu golongan, agama atau kepercayaan, diakui atau dihormati oleh pihak lain. Pengakuan tersebut tidak terbatas pada persamaan derajat, baik dalam tatanan kenegaraan, tatanan kemasyarakatan maupun di hadapan Tuhan Yang Maha Esa, tetapi juga perbedaan-perbedaan dalam cara penghayatan dan peribadatannya yang sesuai dengan alasan kemanusiaan yang adil dan beradab. Dalam toleransi ini semua umat beragama harus berpegang pada prinsip agree in disagreement (setuju dalam perbedaan). 
Prinsip mengenai toleransi antar umat beragama yaitu: (1) tidak boleh ada paksaan dalam beragama baik paksaan itu berupa halus maupun dilakukan secara kasar; (2) manusia berhak untuk memilih dan memeluk agama yang diyakininya dan beribadat menurut keyakinan itu; (3) tidak akan berguna memaksa seseorang agar mengikuti suatu keyakinan tertentu ; dan (4) Tuhan Yang Maha Esa tidak melarang hidup bermasyarakat dengan yang tidak sefaham atau tidak seagama, dengan harapan menghindari sikap saling bermusuhan (Ali, 1986; 82).

Al-Qardhawi (1985, hal. 95-97) berpendapat bahwa toleransi sebenarnya tidaklah bersifat pasif, tetapi dinamis. Sehubungan hal tersebut, al-Qardhawi mengategorikan toleransi keagamaan dalam tiga tingkatan. Pertama, toleransi dalam bentuk hanya sebatas memberikan kebebasan kepada orang lain untuk memeluk agama yang diyakininya, tetapi tidak memberinya kesempatan untuk melaksanakan tugas-tugas keagamaan yang diwajibkan atas dirinya. Kedua, memberinya hak untuk memeluk agama yang diyakininya, kemudian tidak memaksanya mengerjakan sesuatu sebagai larangan dalam agamanya. Ketiga, tidak mempersempit gerak mereka dalam melakukan hal-hal yang menurut agamanya halal, meskipun hal tersebut diharamkan menurut agama kita.

Bentuk toleransi yang harus ditegakkan yaitu: (1) toleransi agama dan (2) toleransi sosial. Toleransi agama adalah toleransi yang menyangkut keyakinan yang berhubungan dengan akidah yaitu sikap lapang dada untuk memberi kesempatan pemeluk agama selain Islam beribadah menurut ketentuan agama yang diyakininya. Sedangkan, toleransi sosial berorientasi terhadap toleransi kemasyarakatan. Dalam masyarakat yang beragam karena perbedaan agama dianjurkan untuk menegakkan kedamaian dan melakukan kerjasama dengan orang-orang yang berlainan agama dalam batas-batas yang telah ditentukan.

Dengan adanya toleransi maka akan dapat melestarikan persatuan dan kesatuan bangsa, mendukung dan menyukseskan pembangunan, serta menghilangkan kesenjangan. Hubungan antar umat beragama didasarkan pada prinsip persaudaraan yang baik, bekerjasama untuk menghadapi musuh dan membela golongan yang menderita.

Toleransi memungkinkan orang untuk memperlakukan orang lain dengan hormat dan bermartabat, memisahkan orang lain dari keyakinan dan praktik sejauh diperlakukan dengan ketidakberpihakan, dan individu dihargai sebagai sesama manusia.

Berdasarkan Penjelasan di atas dapat disimpulkan bahwa toleransi beragama adalah kesadaran seseorang untuk menghargai, menghormati, membiarkan, dan membolehkan pendirian, pandangan, keyakinan, kepercayaan, serta memberikan ruang bagi pelaksanaan kebiasaan, perilaku, dan praktik keagamaan orang lain yang berbeda atau bertentangan dengan pendirian sendiri dalam rangka membangun kehidupan bersama dan hubungan sosial yang lebih baik. 


\section{Kecerdasan Emosi}

Kecerdasan emosi adalah salah satu kunci keberhasilan hidup, orang yang cerdas secara emosi sadar akan keadaan diri dan orang lain, memiliki motivasi dan optimisme. Beberapa penelitian menunjukkan bahwa dari sekian faktor yang menentukan kesuksesan seseorang, kognitif hanya menyumbangkira-kira 20 persen, maka yang 80 persen diisi oleh kekuatan-kekuatan lain termasuk yang disebutnya sebagai kecerdasan emosi (Goleman, 1995, hal. 34).

Kecerdasan emosi merupakan istilah yang relatif baru dalam ilmu psikologi. Dikemukakan pertama kali pada tahun 1990 oleh psikolog Piter Selovey dan John Mayer menerangkan kualitas emosi yang turut menentukan keberhasilan, kualitas tersebut diantaranya adalah; empati, mengungkapkan dan memahami perasaan, mengendalikan amarah, kemandirian, kemampuan menyesuaikan diri, disukai, kemampuan menyelesaikan masalah antar pribadi, ketekunan, kesetiakawanan, keramahan dan sikap hormat (Salovy dan Mayer, 1990, hal. 287).

Goleman (dalam Karim, 2011, hal. 50) adalah salah seorang yang menyebarluaskan kecerdasan emosional melalui bukunya yang berjudul Emotional Intelligence. EI (Emotional Intelligence), yang pada intinya adalah memahami apa arti dan bagaimana membawa kecerdasan kedalam emosi atau membawa pemahaman kognitif kewilayah perasaan (Goleman, 1995, hal. 6).

Selama perkembangannya, sudah banyak para ahli yang mencoba memberikan pengertian terhadap istilah kecerdasan emosi, Salovey dan Mayer (1990, hal. 189) "sebagai pencetus pertamanya" mula-mula memberikan pengertian terhadap istilah kecerdasan emosi sebagai himpunan dari kecerdasan sosial yang melibatkan kemampuan perasaan dan emosi baik kepada diri sendiri atau pada orang lain, memilah-milah semuanya dan menggunakan informasi ini untuk membimbing pikiran dan tindakan. Kemudian dalam perkembangan selanjutnya ia memperbaharui divinisi kecerdasan emosi diartikan sebagai kemampuan untuk mempersepsi secara akurat, menilai, memahami, dan mengekpresikan emosi, kemampuan untuk membangkitkan perasaan pada saat dibutuhkan oleh pikiran dan kemampuan untuk mengatur emosi sebagai pendukung perkembangan emosi dan pemikiran kearah yang lebih baik.

Goleman dalam (Karim, 2011, hal. 50) mendefinisikan kecerdasan emosi sebagai kapasitas untuk mengenali perasaan diri sendiri dan orang lain, memotivasi diri sendiri, mengelola emosi dalam diri sendiri dan dalam hubugan dengan orang lain. Pengertian menurut Goleman sekaligus menerangkan komponen-komponen kecerdasan emosi.

Berdasarkan pengertian-pengertian yang dikemukakan oleh para ahli tersebut maka dapat disimpulkan bahwa kecerdasan emosi adalah kemampuan individu dalam menggunakan aspek kecerdasan atau kognitif dalam mengelola emosi yang tercermin dalam kemampuannya untuk mengenali, memahami, menghargai, mengekpresikan, menggunakan dan mengendalikan emosi diri; 
mengenali, memahami, menghargai, emosi orang lain. Kemampuan ini selanjutnya akan berpengaruh pada kemampuan lainnya, yaitu penyesuaian diri, ketekunan, motivasi, kerja sama, dan kemampuan untuk menjalin hubungan yang produktif.

Goleman dalam (Murphy, 2006, hal. 52) dan (Karim, 2011, hal. 51) membagi kecerdasan emosi kedalam lima wilayah kemampuan utama :

Pertama, kesadaran diri atau mengenal emosi diri adalah mengenali perasaan sewaktu perasaan itu terjadi dan kemampuan membantu perasaan diri dari waktu kewaktu.

Kedua, pengendalian diri atau mengelola emosi, adalah menangani perasaan agar perasaan dapat terungkap dengan pas. Misalnya kemampuan untuk menghibur diri, melepaskan kekecewaan, kemurungan atau ketersinggungan.

Ketiga, motivasi, adalah kemampuan untuk berjuang mencapai cita-cita dengan sikap antusiasme, gairah dan keyakinan diri yang kuat serta berfikir positif tentang sesuatu hal.

Keempat, empati atau mengenali emosi orang lain, adalah kemampuan mengenali, memahami perasaan orang lain dan bertindak bijaksana dalam hubungan dengan sesama. Emosi dapat dibangun berdasarkan kesadaran diri semakin terbuka pada diri sendiri maka semain terampil dalam membaca perasaan orang lain adalah kemampuan membaca perasaan non verbal, seperti nada bicara, gerak gerik atau ekpresi wajah.

Kelima, membina hubungan, adalah kemampuan untuk memahami dan bertindak bijaksana dalam hubungan antar sesama manusia. Hatch dan Gordner, mengidentifikasi kemampuan ini mencakup kemampuan mengorganisir kelompok, merundingkan pemecahan, menjalin hubungan pribadi dan analisis sosial.

Pada konsep yang baru Mayer dan Salovey (Murphy, 2006, hal. 52) mengemukakan bahwa kecerdasan emosi memiliki empat tahap dan masing-masing tahap memiliki empat kemampuan. Tahap pertama adalah persepsi, penilaian, dan ekpresi emosi. Empat kemampuan dalam tahap ini adalah pertama mengenal emosi secara fisik, rasa dan fikir, mengenal emosi pada orang lain, disain, serta seni, dan lain lain, melalui bahasa, bunyi, penampilan dan perilaku; mengungkap emosi secara cepat, membedakan ungkapan rasa antara tepat dan tidak tepat, jujur dan tidak jujur.

Tahap kedua adalah fasilitasi emosi, empat kemampuan dalam tahap ini adalah emosi mampu memberikan prioritas pada fikiran dengan mengarahkan perhatian pada informasi penting, membantu dalam menilai yang berhubungan dengan rasa, mengubah perspektif individu dari pesimis menjadi optimisme, mendorong untuk mempertimbangkan berbagai pandangan.

Tahap ketiga adalah pengertian dan penguraian emosi. Empat kemampuan 
dalam tahap ini adalah mampu memberikan label emosi dan mengambil hubungan antara berbagai kata : mampu mengartikan hubungan emosi dengan hal lain; mampu mengerti rasa yang komplek, mampu mengarah adanya perpindahan emosi. Tahap keempat adalah pengarahan reflektif emosi untuk mempromosikan pengembangan emosi dan intelek. Empat kemampuan dalam tahap ini adalah : mampu tetap terbuka terhadap perasaan, baik yang menyenangkan maupun yang tidak menyenangkan: mampu melibatkan diri atau menarik diri atas dasar pertimbangan dan kegunaan; mampu memantau emosi secara reflektif dalam hubungan dengan diri sendiri maupun orang lain; mampu mengelola emosi diri dan orang lain.

Adapun faktor yang mempengaruhi tinggi rendahnya kecerdasan emosi yang dimiliki seseorang menurut Prayitno (2007, hal. 23) adalah :

Pertama, Kondisi neorologis dan mekanisme kerja otak. Bahwa wilayah prefontal otak mengatur reaksi emosi individu sejak awal. Proyeksi terbesar informasi pengindraan berasal dari talamus kemudian menuju ke otak dan pusat-pusatnya untuk diterima dan diberi makna tentang hal-hal yang diserap. Didalam neo kortek serangkaian tahapan sirkuit mendata dan menganalisis informasi tersebut, memahaminya dan mengatur suatu reaksi melalui lobus frontalis. Apabila dalam proses ini dibutuhkan respon emosional, lobus frontalis akan memerintahkannya. Lobus frontal akan bekerja sama dengan amignala dan sirkuit-sirkuit lain dalam otak emosional, tetapi apabila terjadi pembajakan emosi, urutan mekanisme tersebut tidak berlaku lagi. Pembajakan emosi suatu keadaan dimana ledakan emosi menguasai rasio, pada awalnya dipicu oleh amigdala dan kemudian diikuti oleh kegagalan pengaktifan proses neo kartalis, yang lazimnya menjaga keseimbangan respon emosional. Hal ini akan menyebabkan orang yang bersangkutan tidak mampu berfikir jernih dan mengambil keputusan yang tepat berdasarkan pertimbangan rasionya, sehingga ia akan menunjukkan berbagai tingkah laku maladaptif.

Kedua, Jenis kelaminnya. Faktor yang lain yang dapat mempengeruhi kecerdasan emosi adalah jenis kelaminnya, Anak perempuan lebih trampil berbahasa dari pada anak laki-laki, maka mereka lebih berpengalaman dalam mengutarakan perasaannya dan lebih cakap dalam memanfaatkan kata-kata untuk menjelajahi dan menggantikan reaksi emosional, seperti perkelahian fisik. Sebaliknya, anak laki-laki yang kemampuan ferbalisasi yang perasaannya ditumpukan sebagian besar tampak kurang peka akan keadaan emosi dirinya sendiri dan orang lain.

Ketiga, Temperamen. Setiap manusia memiliki sifat bawaan yang disebut temperamen. Temperamen seorang anak mencerminkan suatu rangkaian emosi bawaan tertentu dalam otaknya, untuk ekpresi emosi sekaligus perilakunya-sekarang dan di masa mendatang. Setiap manusia mempunyai perbedaan dalam jaringan sirkuit emosi yang menyebabkan perbedaan hal seberapa mudahnya emosi dipicu, berapa lama berlangsungnya dan seberapa intensinya. Perbedaan ini menentukan apakah seseorang bersifat pemarah, penakut, periang, pemberani atau pemurung.

Keempat, Pola asuh orangtua. Perkembangan emosi individu (sebagaimana aspek-aspek psikis lainnya) juga dipengeruhi oleh beberapa foktor, mulai dari lingkungan keluarga, lingkungan sekolah sampai lingkungan masyarakat. keluarga terutama orangtua memegang peranan yang penting dalam perkembangan 
kecerdasan emosi anak khususnya.

Kelima, Usia. Efek usia dan jenis kelamin terhadap intensitas emosi menyimpulkan bahwa orang yang lebih muda menunjukkan tingkat rata-rata yang lebih tinggi pada perasaan positif dan negatif. Pada masa remaja akhir individu akan lebih cerdas dalam membuat keputusan, lebih sadar akan bahaya yang timbul, memikirkan akan akibat yang panjang, cenderung untuk memecahkan masalah hati-hati dan dalam membuat keputusan terlebih dahulu mencari informasi yang benar dan mengkaji seluruh alternatif.

Keenam, Teman sebaya. Pada masa remaja individu mulai melepaskan diri dari ikatan keluarga untuk mengembangkan keterlibatannya lebih dekat dengan teman sebayanya. Hal ini cara remaja menemukan identitas diri sebagai pribadi dewasa yang berbeda dengan identitas anak-anak. Tugas-tugas sosial anak dalam persahabatan, antara lain adalah belajar mengelola keinginan diri sendiri dan menysuaikan diri dengan keinginankeinginan teman, belajar mengekspresikan perhatian, mengemukakan keinginan dan perasaan, belajar meminta maaf dan belajar peduli dengan teman.

Ketujuh, Sekolah. Kegiatan-kegiatan yang ada di sekolah merupakan sarana pendidikan emosi dan sosial, murid belajar bekerja bersama, mengemukakan pendapat, mengembangkan pendirian, menghargai orang lain, menyelesaikan pertikaian dan bernegoisasi tanpa menimbulkan perpecahan. Selain itu figur guru juga berpengaruh dalam perkembangan ketrampilan pengelolaan emosi anak. Guru menjadi model anak melalui pengamatan anak terhadap cara guru mengajar, cara memperlakukan murid, dan cara menyelesaikan konflik diantara murid.

Kedelapan, Agama. Agama adalah yang telah menjadi unsur pribadi secara khusus atau otomatis, akan berpengaruh terhadap segala perilaku individu baik dalam berfikir, merasa, bersikap atau bertindak. Harmonisasi yang maksimal antara unsur agama akan menjadi daya kontrol, daya kendali dan daya dorong yang sangat kuatAgama adalah yang telah menjadi unsur pribadi secara khusus atau otomatis, akan berpengaruh terhadap segala perilaku individu baik dalam berfikir, merasa, bersikap atau bertindak. Harmonisasi yang maksimal antara unsur agama akan menjadi daya kontrol, daya kendali dan daya dorong yang sangat kuat.

Berdasarkan penjelasan di atas dapat disimpulkan bahwa factor yang mempengaruhi kecerdasan emosional adalah Kondisi neorologis dan mekanisme kerja otak, Jenis kelaminnya. Temperaman, pola asuh orangtua, usia, teman sebaya, sekolah dan agama

\section{Metode}

\section{Populasi dan Sampel Penelitian}

Populasi dalam penelitian ini adalah seluruh mahasiswa program studi Pendidikan Agama Islam (PAI), Jurusan Tarbiyah, Sekolah Tinggi Agama Islam 
Negeri (STAIN) Kudus yang berjumlah 94 mahasiswa. Adapun tehnik sampling dalam penelitian ini dengan menggunakan teknik convenience sampling. Dalam convenience sampling peneliti mengambil subjek karena mereka ingin dan bersedia untuk diteliti.

Metode yang digunakan untuk memperoleh data dalam penelitian ini adalah angket atau kuesioner, suatu metode yang berdasarkan laporan diri (Selfreport) pengetahuan dalam keyakinan pribadi. Ada dua macam skala yaitu skala kecerdasan emosi dan skala toleransi beragama.

Skala kecerdasan emosi, bertujuan untuk mengungkap tingkat kecerdasan emosi subjek, konstruksi skala disusun sendiri oleh peneliti dengan mengacu pada Goleman dalam Karim (2011, hal. 51). Kecerdasan emosi menurutnya meliputi lima komponen yaitu kesadaran diri, pengendalian diri, motovasi, empati dan membina hubungan. Untuk mengungkap kelima aspek tersebut disusun sebanyak 35 butir pada setiap pernyataan butir terdapat empat pilihan jawaban yaitu: Sangat Setuju (SS), Setuju (S), Tidak setuju (TS), Sangat tidak setuju (STS). Untuk melihat tingkat konsistensi jawaban, pertanyaan disusun dalam dua bentuk yaitu favorable (positif) dan unfavorable (negatif). Secara keseluruhan reliabilitas skala kecerdasan emosi sebesar 0,93 .

Adapun skala toleransi beragama digunakan disusun berdasarkan komponen berupa keyakinan dan penghormatan terhadap pelaksanaan ritual dan pendirian rumat ibadat, dan kerjasama sosial pada individu yang memegang keyakinan dan praktek ibadah yang berbeda. Secara keseluruhan, skala toleransi beragama berjumlah 30 butir dengan reliabilitas sebesar 0,80 . Tehnik analisis dalam penelitian ini dengan menggunakan analisis regresi sederhana.

Teknik yang digunakan untuk menganalisis data dalam penelitian ini yaitu analisis regresi. Regresi ini digunakan untuk menguji hubungan antara kecerdasan emosi dengan toleransi beragama.

\section{Hasil}

Sebelum dilakukan uji hipotesis, akan dipaparkan terlebih dahulu data deskriptif penelitian untuk tiap variabel. Deskripsi statistik data penelitian diringkas pada tabel 1 berikut:

Tabel 1. Deskripsi data penelitian

\begin{tabular}{cccccc}
\hline Variabel & N & Minimum & Maximum & Mean & Std. Deviation \\
\hline Kecerdasan Emosi & 94 & 4 & 26 & 13.75532 & 5.654356 \\
Toleransi Beragama & 94 & 2 & 12 & 9.606383 & 2.476635 \\
Valid N (listwise) & 94 & & & & \\
\hline
\end{tabular}

Berdasarkan tabel 1 di atas diketahui untuk variabel kecerdasan emosi skor rerata empiriknya sebesar 13,755, dengan nilai standar deviasi sebesar 5,654, 
sedangkan pada variabel toleransi beragama skor rerata empiriknya sebesar 9,606 dengan nilai standar deviasi sebesar 2,476.

Setelah diketahui deskripsi masing-masing variabel kemudian dilakukan uji hipotesis hubungan antara kecerdasan emosi dengan toleransi beragama mahasiswa. Adapun hasil uji hipotesis diringkas pada tabel 2 berikut:

Tabel 2: Hasil uji hipotesis

\begin{tabular}{lcrrr}
\hline \multicolumn{1}{c}{ Variabel } & R & R Square & Signifikansi & Keterangan \\
\hline $\begin{array}{l}\text { Kecerdasan Emosi Terhadap } \\
\text { Toleransi Beragama }\end{array}$ & 0.458 & 0.209 & .000 & $\begin{array}{r}\text { Sangat } \\
\text { signifikan }\end{array}$ \\
\hline
\end{tabular}

Berdasarkan hasil uji hipotesis diperoleh $r=0,458 ; p=0,000$. Dengan demikian, hipotesis yang menyatakan bahwa ada hubungan positif yang signifikan antara kecerdasan emosi dengan toleransi beragama mahasiswa terbukti. Pada tabel 2 di atas juga menunjukkan bahwa $\mathrm{R}^{2}$ mempunyai nilai 0.209 , yang berarti kecerdasan emosi mempunyai sumbangan efektif 20 persen terhadap toleransi beragama mahasiswa.

Kecerdasan emosi adalah kemampuan individu dalam menggunakan aspek kecerdasan atau kognitif dalam mengelola emosi yang tercermin dalam kemampuannya untuk mengenali, memahami, menghargai, mengekpresikan, menggunakan dan mengendalikan emosi diri, mengenali, memahami, menghargai emosi orang lain. Kemampuan ini selanjutnya akan berpengeruh pada kemampuan lainnya yaitu penyesuaian diri, ketekunan dan motivasi, kerja sama dan kemampuan untuk menjalin hubungan yang produktif.

Orang yang cerdas emosinya akan mampu mengenali keadaan emosional mereka sendiri dan keadaan emosional orang lain dan sebagai akibatnya individu tersebut lebih mudah berhubungan dengan orang disekitarnya, baik dalam bidang agama, akademik, ekonomi, pekerjaan, maupun saat bercanda dengan teman-teman, begitu pula sebaliknya seorang individu yang mempunyai kematangan beragama berhubungan dengan kecerdasan emosi yang baik pula. Individu yang memiliki kematangan beragama akan menunjukkan kelebihannya dalam memahami, menghayati serta mengaplikasikan nilai-nilai luhur agama yang dianutnya dalam kehidupan sehari-hari.

Hasil penelitian ini sesuai dengan penelitian Brackett, Mayer dan Warner (2004, hal. 1387) di mana dengan individu mempunyai kecerdasan emosional yang baik dapat menjadi prediktor kuat dalam penyesuaian diri dan perilaku individu. Bahwa kecerdasan emosional mempunyai keterkaitan secara negative dengan penyesuian yang buruk dan perilaku yang negative bagi sampel mahasiswa laki-laki dan tidak untuk perempuan.

Hasil penelitian ini juga sesuai dengan penelitian yang dilakukan oleh Sadri dan Janani (2015, hal. 9-18) yang menunjukkan bahwa kecerdasan emosional mempunyai korelasi positif yang signifikan dengan regulasi diri pada atlit renang di 
negara Azerbaijan. Hal ini menunjukkan bahwa kecerdasan emosional mempunyai peran penting dalam pengelolaan diri.

Berdasarkan hasil penelitian ini menunjukkan bahwa individu yang memiliki tingkat kecerdasan emosional yang tinggi akan menunjukkan sikap asertif, yaitu sikap tegas dalam mengemukakan pendapat, tanpa harus melukai perasaan lawan bicara. Orang yang assertif ini tahu betul kapan harus bicara, mengemukakan suatu pendapat dan bagaimana cara yang tepat untuk memberikan sebuah solusi tanpa menggurui. Dan yang pasti individu yang memiliki sikap assertif sebelum bicara akan memikirkannya terlebih dahulu, tidak asal bicara.

Individu dengan kecerdasan emosional tinggi, tahu bagaimana memanfaatkan energi mereka dengan bijak, bersikap positif menyikapi masalah bisa membawa pada solusi yang tepat untuk menyelesaikan permasalahan. Individu tersebut akan fokus pada tindakan-tindakan yang akan membawa manfaat bagi sesamanya.

Individu dengan kecerdasan emosional tinggi, akan menghargai dan bersikap toleran terhadap individu yang berbeda keyakinan, agama, tidak memaksa mereka mengikuti agamanya dan tidak mencampuri urusan agama masing-masing.

\section{Simpulan}

Berdasarkan hasil penelitian ini, maka dapat disimpulkan bahwa ada pengaruh yang positif kecerdasan emosi terhadap toleransi beragama pada mahasiswa. Semakin tinggi skor kecerdasan emosi yang diperoleh mahasiswa semakin tinggi pula toleransi beragama yang dimiliki mahasiswa. Hasil penelitian ini memberikan penjelasan dan penegasan tentang pentingnya kecerdasan emosi dalam kehidupan, khususnya dalam kehidupan yang majemuk seperti perbedaan suku, bahasa, etnis dan agama dalam rangka meningkatkan toleransi atas perbedaan. 


\section{Referensi}

Ali, M. D. (1986). Islam Untuk Disiplin Ilmu Hukum, Sosial dan Politik. Jakarta: CV. Wirabuana.

Al-Munawar, S. A. H. (1987). Fikih Hubungan Antar Agama. Jakarta: Penerbit Ciputat Press.

Al-Qardhawi, Y. (1985). Minoritas Nonmuslim di dalam Masyarakat Islam. Terj. Muhammad Baqir. Bandung: Mizan.

Brackett, M. A., Mayer, J. D., \& Warner, R. M. (2004). Emotional intelligence and its relation to everyday behavior. Personality and Individual Differences, 36, 13871402.

Ghufron, M. N., \& Risnawita, R. (2010). Teori-teori Psikologi. Yogyakarta: AR-RUZ Media.

Goleman, D. (1995). Emotional Intelligence: Why it Can Matter More than IQ. New York: Bantam.

Khisbiyah,Y.(2007).MenepisPrasangka, MemupukToleransiuntukMultikulturalisme: Dukungan dari Psikologi Sosial. Surakarta: PSB-PS UMS.

Lagattuta, K. H., \& Wellman, H. M. (2002). Differences in Early Parent Child Conversation About Negative Versus Positive Emotion: Implication For The Developmen of Psyc hological under Standing. Journal Developmental Psychology, 38(4), 564-580.

Manaf, M. A. (1994). Ilmu Perbandingan Agama. Jakarta: PT. Raja Grafindo Persada.

Ghufron, M. N. (2015). Sejahtera secara Spiritual dengan Pendidikan Agama. Dipresentasikan pada Seminar Nasional Educational Wellbeing, Universitas Muria Kudus.

Murphy, K. I. (2006). The Relationship between Emotional Intelligence and Satisfaction with Life After Controlling for Self-Esteem, Depression, and Locus of Control among Community College Students. Graduate Theses and Dissertations. Florida: University of South Florida. Diambil dari http:// scholarcommons.usf.edu/etd/2640.

Nasution, H. (1985). Islam Ditinjau dari Berbagai Aspeknya (Jilid I). Jakarta: UI Press.

Prayitno, N. (2007). Hubungan antara Kematangan Beragama Islam dan Pola Asuh Denokratis Dengan Kecerdasan Emosi pada Remaja (Tesis tidak dipublikasikan). Universitas Gadjah Mada Yogyakarta. 
Priyadarshini Das, P. P., \& Tripathy, S. (2015). Role of Emotional Intelligence on Aggression: A Comparison between Adolescent Boys and Girls. Psychology and Behavioral Sciences, 4(1), 29-35. doi: 10.11648/j.pbs.20150401.15

Puslitbang Kehidupan Keagamaan Badan Litbang dan Diklat Kementerian Agama RI. (2010). Toleransi Beragama Mahasiswa (Studi tentang Pengaruh Kepribadian, Keterlibatan Organisasi, Hasil Belajar Pendidikan Agama, dan Lingkungan Pendidikan terhadap Toleransi Mahasiswa Berbeda Agama pada 7 Perguruan Tinggi Umum Negeri). Jakarta: Badan Litbang dan Diklat Kementerian Agama.

Sadri, A., \& Janani, H. (2015). Relationship of Emotional Intelligence and Selfregulation of Male Elite Swimmers. Annals of Applied Sport Science, 3(4), 0918.

Tice, D. M., Bratelavisky, E., \& Baumemister, R. F. (2001). Emotional Distress Regulation Takes Presedence.Over Impulse Control: If You Feel Bad. Do it ! Journal of Personality and Social Psychology. 80(1), 53- 67. 